\title{
Introduction: conceptualizing women, gender and rural development in China
}

\section{Tamara Jacka and Sally Sargeson}

Between the 1980s and the first decade of the 21st century, China's rapid, sustained economic growth brought great benefits to rural citizens. According to the United Nations Development Programme (UNDP), for example, between 1978 and 2007 the real annual growth rate of rural per capita net income reached 7.1 per cent, and the number of rural people in absolute poverty declined from 250 million to 14.8 million (UNDP 2008: 10-11, 13). Rural life expectancy and literacy rates also improved dramatically. To many observers, these changes constituted nothing less than a 'developmental miracle' (So 2003). It was also noted, however, that China's rapid economic growth had coincided with an increase in the types of rural-urban, regional and social disparities, environmental degradation and unrest that characterized other developing countries. Of particular concern to women's advocates, some achievements that had been made in previous decades in reducing gender inequalities in rural political representation, income and education were being reversed (Tan Lin 2006; Tan Lin and Bohong Liu 2005).

Growing concern about the scale and severity of these issues prompted what has been represented widely as a major re-orientation of approaches to rural development by China's leadership. In 2003, the incoming Chinese Communist Party regime led by $\mathrm{Hu}$ Jintao and Wen Jiabao committed itself to shifting from a focus on promoting aggregate economic growth, to placing 'integrated urban-rural development' at the forefront of state efforts to create an harmonious, 'people-centred', 'well-off' society.

For development scholars and women's advocates alike, one of the key questions to emerge from this reorientation is whether or not we are witnessing a shift from a model in which gender equality in rural areas is viewed largely as a concomitant of economic growth, to an approach that enables rural women to pursue their own development goals. This is the overarching question that we seek to address in this book. More specifically, we ask, how are women and gender conceptualized in, and mobilized by the rural development policies and projects issuing from 
the state and international and domestic organizations? In what ways is rural development reducing, transforming or reinforcing gender inequalities in power, resources and opportunity? To what extent, and with what consequences, are different women able to bring their own understandings of, and desires for development to bear in the momentous changes being wrought in China's countryside? To paraphrase Klenk (2004), who is the gendered subject, 'rural woman', that figures in contemporary approaches to rural development in China?

Despite differing in their focus on the actions of women from disparate areas of China and on a variety of policies, campaigns and projects engineered by different agencies, the contributors to this volume share the common view that in order to address these questions we must consider how gendered power relations interact with development discourses, institutions, policies and interventions, to influence the desires, agency and dispositions of different women in rural China today. It is from this perspective that we engage with arguments advanced in three influential fields of literature. In the first of those fields, theorists of development have articulated an incisive critique of development as a modernization telos that is instrumental in expanding the power of the state (Ferguson 1994) and reinforcing neo-colonial power relations between development agencies and subject-beneficiaries (Escobar 1995). The second body of scholarship deconstructs the Western, liberal masculinist models of individual agency and empowerment that underpin, and are deployed in, contemporary strategies of 'participatory' development, and illustrates how these simultaneously serve to represent women as vulnerable, passive victims of patriarchal traditions and instil in them aspirations for independence and power, whilst distracting attention from contemporary political, economic and institutional sources of gender inequality (Green 2000; Parpart 1993). Thirdly, China analysts have criticized the organizational and institutional frameworks created to serve the developmental goals of the Chinese Communist Party (hereafter, CCP) and government for failing to admit villagers' participation in 'problem identification', as well as the planning and implementation of rural development solutions (Chen, Lanyan 2008; Ho et al. 2004).

The contributors to this volume offer some qualified empirical support for each of these sets of arguments. Equally importantly, however, their analyses demonstrate that many women are making use of the material, discursive and organizational resources produced for and by rural development for their own purposes, in ways that shape different local processes and outcomes of development. Furthermore, development has facilitated the dissemination of gender equality as an ideal and institutional norm in the countryside, increased the channels through which 
women can advance claims for gender equal rights, resources and treatment, and expanded the agentic roles available to them.

What are we to make of this apparent contradiction? In keeping with other feminist analysts (Ortner 2006; Tinsman 2000), we argue that development involves projects that simultaneously might extend the power of the state, organizations and activists to discursively construct the subjectivity of development participant-beneficiaries, while also expanding the capacities of those participant-beneficiaries to conceive of, and pursue goals that are not mere reflections of, or reactions against, the ideologies, goals and methods of the powerful. This point is most clearly illustrated by the contributions of Sargeson and Song, Huang, Ingram, Ross and Wesoky, which detail how, in the course of dealing with the expropriation of their land, commodification and exploitation of their labour, and insertion into 'civilizing' educational and political programmes, women have claimed rights, resources and positions that have enhanced their ability to reflect on and pursue choices, and exercise greater influence in their households and communities.

The aim of this introduction is to outline how the contributions to this volume illuminate how women's agency is being scripted, resourced and reconfigured in the course of contemporary China's rural development. We begin by examining the role of key development actors - China's state, the All China Women's Federation (hereafter, Women's Federation), ${ }^{1}$ the key authority representing women's interests, and non-governmental organizations (NGOs) and international donor agencies - in the making of a 'new' approach to rural development in China at the beginning of the 21 st century. Much of the extant literature on this 'new' approach focuses on the extent to which it actually is 'new', and whether it is effective in achieving pre-determined development goals. From our vantage point, however, a critically important feature of this approach is that gender relations have largely been elided in the identification of rural development problems, and in the formulation and implementation of development solutions. In the guise of a backward, vulnerable and underutilized group, however, rural women are central to both. We interrogate how this representation of rural women informs development policy discourses, projects and practices, and what these mean for the ways in which rural women envisage and enact roles as development participant-beneficiaries. In the second section of the introduction, we explain how these themes are illustrated in the subsequent chapters of the book. 


\section{A 'NEW' APPROACH TO RURAL DEVELOPMENT IN CHINA?}

Although the 'miracle' development of rural China became a staple of media and scholarly commentary in the 1980s and 1990s, it is worth recalling that for much of the 20th century, China's leaders viewed the countryside as a brake on the country's modernization (Wen, Tiejun 2001). The persistence of 'feudal' patriarchal relations in rural production, social reproduction, governance and citizenship was held up as emblematic of all that was pre-modern and antithetical to China's development as a strong nation (Edwards 2008). In the words of Qin Hui, Professor of History at Qinghua University, 'Before we had the saying "The Chinese question is essentially the problem of Chinese peasants." Now we should rather say "The peasant question is essentially the problem of China's modernization"” (2003: 139). The problematization of rurality in this teleological discourse was temporarily suspended in the 1980s, when the dismantling of communes, the liberalization of prices and the expansion of markets, along with the contracting of collectively-owned farmland to households, acted as a stimulus to agricultural productivity, rural industrialization and villagers' incomes. Indeed, in 1984 the State Council, the highest organ of executive government in China, announced that rural industry had become an important driving force of the national economy (Zhang, Zhihong 1999).

At the end of the 20th century, however, a series of reports and bestselling books in Chinese focused the attention of both policy makers and the public on three problems that were contributing to an unfolding 'rural crisis' (see, for example, Chen Guidi and Tao Chun 2004). Summed up in the pithy phrase penned by Li Changping, Party Secretary of a township in Hubei, in a letter directly addressed to Premier Zhu Rongji in March 2000, 'villagers are very poor, rural life is hard, and agriculture is in crisis' (Li Changping 2002: 20). Pointing to growing rural-urban inequalities in wealth, consumption and welfare, widespread protests against the arbitrary and excessive taxation of villagers and the emergence of a burgeoning village population deprived of their farmland by developers, some commentators went so far as to warn that a rural lumpen proletariat was threatening the nation's stability and security (Sargeson 2004: 648).

These exposés prompted China's leaders to concede that a new approach to rural development was needed, one which focused on creating a more harmonious, equitable society and employed 'a different kind of government intervention, from developmental and command-and-control to more targeted, decentralized and consensual approaches' (Ho et al. 2004: 7; Su, Minzi 2009; Ye, Xingqing 2009). To encourage farmers' investment 
in agriculture, the Rural Land Contract Law of 1998 lengthened the duration and strengthened the security of land contracts. Beginning with tax reforms in 2000, and proceeding through to the introduction of subsidies for agricultural production in 2004 and the nation-wide elimination of the agricultural tax in 2006, China's government sought to alleviate the costs of agricultural production. Township governments were directed to consult with villagers when transacting collective property, and new regulations required transparency in village elections, decision making, management and supervision. In 2002, the 16th National Congress of the CCP resolved that, henceforth, rural development would be central to China's efforts to create a 'well-off', harmonious society.

It was under the leadership of President $\mathrm{Hu}$ Jintao and Premier Wen Jiabao, however, that in 2003 a multiplicity of ad hoc initiatives were knitted together into what Christiansen and Zhang (2009: 7) describe as a 'strategically coherent, ideologically justified and practically coordinated approach' to rural development. Practical 'people-centred' ( $y$ i ren wei ben) strategies to promote rural development through the integration of urban and rural areas were set out in the six consecutive No. 1 Documents issued annually by the State Council, from 2004 to 2010 . The comprehensive, farreaching nature of what the leadership envisaged for rural China was first conveyed in October 2005, in the CCP Central Committee's announcement of its commitment to build a 'New Socialist Countryside' (Wen Jiabao 2006; Wu Yunhe 2008).

In the following State Council No. 1 Document of 2006 and 11th Five Year Plan covering the years 2006-2010, strategies were outlined and new funds allocated to: modernize agricultural production; raise rural incomes through increases in agricultural productivity and non-agricultural employment; reconstruct villages and provide physical and communications infrastructure; protect the environment; eliminate fees for compulsory schooling; create universal rural cooperative medical insurance and social welfare systems; and improve democratic grassroots governance.

In a second set of announcements in 2008, the CCP Central Committee proposed stepping up the reform of three institutions that had underpinned systemic structural bias in the economy and reproduced rural/ urban inequalities since the 1950s: the systems of residential registration (hukou) ${ }^{2}$ the rural collective land regime; and political representation (Ye, Xingqing 2009). A new set of reforms to the hukou system was intended to enable people registered as rural residents to enjoy equal labour rights and the same access to education, housing and social welfare, as urban residents. The relaxation of restrictions on rural collectives' transfer of rights to use and develop land were aimed at consolidating landholdings, facilitating agricultural mechanization, and enabling collectives to invest 
in rural infrastructure and social protections. Changes to the Electoral Law, to provide for equal proportionate representation of urban and rural delegates in China's legislature, the People's Congresses, would ensure that people from the countryside would enjoy commensurate input into key appointments, budgets, legislation and policy (Nilsson 2010).

This 'new' integrated approach to development through 'urban-rural integration' was justified ideologically by reference to the leadership's socialist 'scientific development outlook' on the country's historical progress. China, reasoned $\mathrm{Hu}$ Jintao, had reached a stage in its evolutionary modernization when industry must support agriculture, and urban areas support rural areas (Chen, Xiwen 2009). In domestic media, much was made of the extent to which the approach reflected the leadership's respect for Confucian 'minben' (people as the foundation) principles, according to which the people constitute the foundation of the state and the primary responsibility of government is to ensure social harmony by meeting the people's basic needs (see, for example, Huang Hui 2006; Wen Jiabao 2004). For foreign audiences, emphasis was placed on the overlap between China's 'new' strategies to improve villagers' livelihoods and participation in decision making, and the humanist plans of global development agencies, manifest in the UN's Millennium Development Goals (UNDP 2009: vii). For example, measures aimed at improving villagers' participation in poverty alleviation, agricultural extension services and governance were incorporated into China's national development plans.

Few have questioned whether government investment in rural development increased under $\mathrm{Hu}$ and Wen's leadership. Rather, the scholarly debates sparked by their prioritization of rural development centred on whether or not their approach was, in any meaningful sense, novel, whether 'people-centred' rhetoric had translated into popular participation, and whether 'urban-rural integration' would effectively alleviate the problems of poor villagers, rural hardship and agricultural crisis (Ahlers and Schubert 2009). Su, Minzi (2009) and Smith (2009), for example, argued that despite the new stress on participation, interventions continued to be characterized by top-down paternalism, and the government's campaign-style approach to mobilization, obsession with quantifiable outputs, and investment in already well-endowed model villages. In contrast, a World Bank report attributed lack of participation not to the government's authoritarian methods but, rather, to 'a paucity of incentives for local people to organize' (World Bank 2007: 83). In assessing outcomes, Guo, Xiangyu et al. concluded that 'only the few relatively strong industrial provinces show significant development in their rural economies' (2009: 324), while Chen Xiwen accused local governments of using 'urban-rural integration' as an excuse for further land grabbing $(\mathrm{Li}$, 
Xing 2010). Conversely, Liu, Chengfang et al. (2009) argued that both infrastructure quality and villagers' level of satisfaction with development projects had improved.

What we find remarkable about this diagnosis of a 'rural crisis' and elaboration of a 'new' rural development approach, however, is, first, that the designation of development continued to reflect the valorization of a particular trajectory and form of modernity, by urban and predominantly male policy elites. State promotion of agri-business, industrialization and urbanization still comprised the main strategies of rural development, and the end remained the creation of a modern citizenry whose 'responsible' agency would be directed towards strengthening the nation (Lei 2010: 325). Second, and most importantly for the subject of our inquiry, gender has largely been overlooked. Nowhere, in either the leaders' major speeches identifying items of concern, or the No. 1 Documents setting out the framework for promoting rural development, was mention made of widening gender disparities as a serious development problem or a major focus for policy intervention. Indeed, as Ross points out in Chapter 6, even in the '2020 Blueprint' for educational reform which sets 'overcoming disparity' as a key goal, gender is ignored (China, Ministry of Education 2010). Nor, according to some of the leading Chinese development experts involved in an impact assessment for the UNDP, has gender routinely been incorporated into domestic policy analysis (UNDP 2010: vii; see also Song et al. 2006: 136).

On the other hand, although gender has been disregarded in the 'new' approach to rural development, rural women have been singled out for a great deal of attention. A growing body of literature has represented rural women as a burdensome, backward group impeding modernization of the countryside; a 'vulnerable group' (ruoshi qunti), characterized by lack, insecurity and helplessness; and an underutilized population whose labour should be deployed more effectively in the construction of the New Socialist Countryside and the nurturing of a 'modern' citizenry. In this multi-layered, gender-freighted narrative, lagging agricultural productivity has been explained as a consequence of the purported 'feminization' of farming following increased male out-migration from villages. China Women's News (2006) and Zhong and Di (2005), for example, reason that village women's internalization of 'traditional' gender norms, their limited education, 'low quality' (suzhi di) and inherently risk-averse character, slows the take-up of new technologies in agriculture, limiting productivity and profitability and so constraining families' investment in the education of children. Rural women thereby play a role in perpetuating the vicious cycle of rural underdevelopment. Meanwhile, women 'left behind' (liushou) by migrant husbands have been grouped together with 'left behind' children, the elderly and infirm, as a category 
of vulnerable dependents - akin to what Enloe (1990) refers to as the infantilized collective subject 'womenandchildren' - that is 'accustomed to being helped by society or men' (China Women's News 2006; see also, $\mathrm{Xu}$ Chuanxin 2009). To benefit from, and participate as agents in development, this group requires protection, instruction and 'empowerment' from a paternalistic state. In this regard, the masculinist state agencies involved in rural development are to rural women what urbanization is to the countryside: a means of modernization.

This discursive problematization of rural women as a backward, vulnerable, but also potentially instrumental group is consistent with the practical and theoretical positions historically taken by the state organizations involved in rural development in China, including the Women's Federation. Since the early 1990s, the centrepiece of the Women's Federation's work in rural China has been the 'two studies, two competitions' (shuangxue shuangbi) programme, which focuses on vocational training to raise women's 'quality' (Judd 2002). Through these activities, the Women's Federation has sought simultaneously to improve women's status by increasing the visibility and remuneration of their work in income-earning production, and mould them into rational, entrepreneurial citizens who possess the human capital necessary to compete in a market economy and participate in self- and community governance. These twin goals correspond with the key materialist propositions of both Marxist emancipatory theory and liberal feminist Women in Development (WID) discourse, ${ }^{3}$ that women's economic participation is a precondition for equality, and women's equality is conducive to development. These instrumental links are made explicit in Section 2 of China's White Paper, Gender Equality and Women's Development in China:

The state has made the guarantee of equal employment opportunities between women and men and the sharing of economic resources and results of social development the top priority for the advancement of gender equality and the development of women, and has worked out and adopted a series of policies and measures to ensure that women can equally participate in economic development, enjoy equal access to economic resources and effective services, enhance their self-development ability and improve their social and economic status...

Government departments and Women's Federations at all levels have jointly organized activities to encourage rural women to acquire knowledge and learn science and technology, and compete in their development and contributions, so as to bring their role in invigorating and developing the rural economy into full play. (People's Republic of China, 2005).[/quotation]

The above quotation, however, also is suggestive of a subtle but profoundly important shift in the Chinese state's representation of 
gender inequality in economic participation, and how it relates to rural development. It was a common refrain of the state led by Mao Zedong, that 'what men can do, women can do too'. In post-Mao era slogans, in contrast, 'women and men are different'. Hence, although laws consistently affirm gender equality, the role women are encouraged to play in 'invigorating and developing the rural economy' also, 'naturally', differs from that of men's. The focus of Women's Federation work consequently has moved away from remaking the structures, institutions and norms that produce gender inequalities in rural economic participation, towards remaking rural women. Ergo, women are being trained to develop themselves, their households and communities, by cultivating a new, open, 'mind-set', acquiring the technical skills suited to commercial agriculture and in demand from employers, and parenting more highly educated, civilized children.

This emphasis on the need for rural women to develop themselves reproduces three key elements of the powerful neo-liberal ethos that swept the world in the late 20th century. As in neo-liberalizing polities more generally, the Chinese state's role in development has increasingly centred, first of all, on 'freeing up' and providing infrastructure to support market forces. Second, it vests responsibility in individuals and encourages them to exercise a narrowly defined form of economic and civic agency, to participate in markets and self- and community governance. Third, some individuals are viewed as more capable of competition, self-development and self-government than others (Hindess 2001; Ong 2006). In particular, as Tomba (2009) has written, the urban middle class is being groomed by the state as the model of self-government, market rationality and national modernization. In contrast, in both official and popular discourse, the rural population, especially rural ethnic minority groups and women, are regarded as lacking the 'quality' necessary for self-development. Consequently, they are to be subjected to more direct forms of state regulation, paternalistic discourses of 'protection', 'assistance', 'education' and 'empowerment', and, of course, the salutary influences exerted by processes of urbanization.

The Women's Federation has responded to this developmental discourse by attempting to get a 'bigger piece of the pie' for rural women, in part by emphasizing where women are excluded or lacking, and their vulnerability. Parpart (1995) has noted that use of the term 'vulnerable groups' was first promoted in the 1980s by the Commonwealth Expert Group on Women and Structural Adjustment as a strategic way of drawing attention to the adverse effects of the World Bank's structural adjustment policies for women and other disadvantaged groups. There was a similar rationale for the term's take-up by women's representatives 
in China, and it has had similar effects: strategically, it served as a cover under which the Women's Federation bids for additional funding from the state, to direct much-needed resources into programmes for poor, rural women and 'gender-mainstreaming'. Simultaneously, however, it has 'further entrenched the image of the helpless premodern, vulnerable Third World woman' (Parpart 1995: 229; see also, Jacka 2006b: 74).

The Fourth World Women's Conference on Women, held in Beijing in 1995, heralded two important shifts in the approach to gender issues taken by the Chinese state and Women's Federation. The first was a tolerance of growing numbers of NGOs and foreign donor-funded projects working to overcome gender inequalities in rural China. The second was a commitment to 'gender mainstreaming'. At first, these two new initiatives seemed to promise more effective approaches to overcoming gender inequalities than those previously pursued. As we discuss in the following paragraphs, however, their recent progress and impact have been limited.

At the national level, the Chinese state charged the Women's Federation with promoting 'gender mainstreaming'. In principle, this meant the Women's Federation would ensure that gender equality was addressed in the structure, staffing, budgets and policies of all state organizations, and that men and women would be treated equally and equitably in all legislation and policy. However, the Women's Federation possessed neither the political and administrative clout nor the resources to mainstream gender equality even within government organizations, and its activities in the state arena largely focused on box-ticking and the training of and reporting on exemplary women leaders. Similarly, its calls for gendersensitivity and warnings about the potentially adverse gender impacts of legislation and policy on rural women have frequently fallen on deaf ears. The eclipse of rural women's interests in recent property laws illustrates the latter point. The authors of the 2002 Rural Land Contract Law ignored submissions from not only the Women's Federation, but also the Ministry of Agriculture Research Office and Academy of Social Sciences, advising that the law allows the readjustment of contract land periodically so as to provide land shares to women, most of whom move to their husbands' home at marriage and, by custom, can no longer farm land in their natal villages. Suggestions that household land contracts be signed by all farming adults so as to protect women's rights were rejected by policy elites committed to the economically liberal goals of strengthening contractors' rights and promoting the market circulation of farmland, and the gender-conservative goal of preserving unitary 'household-based' agriculture. For the same reason, women's advocates' criticisms of provisions in the 2007 Property Law were set aside, and the Law consequently allowed land contract signatories, the vast majority of whom are male, 
to sell and, in some areas, mortgage their use-rights without gaining their spouses' consent (Liaw 2008: 251). Not surprisingly, researchers have subsequently found that women are disproportionately represented among the growing population of 'landless villagers' (He Lirong 2008; Wang Zhuqing 2007; Yang, Li and Yinsheng Xi 2006; Zhang, Linxiu et al. 2008).

Expanding the numbers of women's NGOs and international NGOs (INGOs) working to reduce gender equalities through 'participatory' approaches and Gender and Development (GAD) programmes initially seemed to provide organizational and methodological alternatives to the state's instrumentalization of women in rural development. Ross (this volume) argues that these organizations have strengthened awareness of women's rights of association and citizenship and nurtured female leadership. Certainly, most of the agencies have included gender equality in their project goals, and several of the most prominent international organizations, including the Ford Foundation, Oxfam, the Global Fund for Women and UNIFEM, have funded projects and programmes that specifically target gender inequalities in rural areas. Moreover, many have involved local branches of the Women's Federation in project implementation in order not only to secure state approval and access to rural sites, but also to better 'mainstream' gender equality goals and resources. Finally, the incorporation of 'participatory' and GAD discourses ${ }^{4}$ in donor-funded projects implicitly challenged the state's construction of rural women as 'low quality', vulnerable subjects in need of protection and guidance from outside development agents.

Ironically, however, many donor-funded projects align neatly with the state's vision of why and how rural women are to be developed. The most common goals of NGO and INGO projects targeting gender inequalities are to bring about improvements in three key areas: women's income generation (through skills training and micro-credit); reproductive and maternal and child health; and girls' education. Nowhere is the interface between INGO projects and the state's vision closer than in gender education interventions. As Ross shows in Chapter 6, the Spring Bud programme to educate rural girls dovetails with state education policies that define women as 'mediators of modernization', because improvements in their personal competence are viewed as the key to reducing poverty, improving the population's 'quality', and strengthening the nation. And for all the rhetorical emphasis placed on gender, it is by no means clear that donor-aided GAD projects contest either the organizational cultures or the institutions through which gender inequalities are reproduced in the course of rural development. On the contrary, Yang's case study in Chapter 9 shows that donor-funded projects often provide revenue for 
County Women's Federations, even though 'their cooperation tends to be contingent on the project containing easily achievable, economically quantifiable targets and no political risk'. Nor do donor-funded gender equality projects necessarily contest even the most powerful norms underpinning unequal gender relations. Jacka (2010) has noted elsewhere, for example, that GAD-inspired community development programmes run by the Shaanxi NGO, WestWomen, make little effort to alter assumptions about gender divisions of labour. Instead, they tend to exploit women's labour in the traditionally 'female' areas of health and family welfare, while leaving men's dominance of formal village political institutions undiminished. This raises the possibility that one of the most significant practical effects of NGO and INGO projects has been to serve, rather than to counter, the state's and Women's Federation's instrumentalization of women in rural development.

Feminist scholars and development practitioners in China have tried to build on globally-inspired 'participatory' and GAD discourses to improve and, in some cases, challenge the state's and Women's Federation's approaches to gender and development. Yet, as Zhao explains in Chapter 7 (see also Ye, Jingzhong 2008), partly because of the attraction of international donor funding and the consequent power of donor agencies to shape project agendas, there has been little sustained critique of these discourses within China. Instead, NGO activists tend to assume that GAD and 'participatory development' approaches are superior to those taken by the state and the Women's Federation, and fail to see the congruence between them. To be sure, some, including Gao Xiaoxian (2005), have recommended that GAD concepts and terminology should be 'indigenized'. But there has been little investigation into the political economy of knowledge production - the structures, political processes and sets of power relations at the international, national and local levels that shape how the keywords 'development', 'participation' and 'empowerment' are defined and harnessed to strategic agendas in China. Few analysts have acknowledged that, although some terms central to global development-speak, including 'development' and 'equality', have a long, potent history in the politics of rural China, others, including 'participation', 'agency' and 'empowerment', are new and, to most rural people, are meaningless or carry connotations very different from those associated with the concepts in other places. Finally, Chinese critiques of rural development interventions tend to focus on technical obstacles, or the limited ability of 'traditionallyminded' women to capitalize on programmes aimed at enhancing their 'quality', 'participation' or 'empowerment'. Comparatively little attention has been paid to the dispositions of different rural women with respect to 'development', or the ways in which they experience, appropriate and 
use for their own purposes, deflect or are affected by, rural development agencies, institutions and resources.

Thus, the central questions that this volume seeks to address are, who are the 'rural women' that simultaneously have been elided in China's 'new' approach to rural development, and are discursively constructed and mobilized in development policies, discourses and projects in contemporary China? What kinds of women-subjects, enmeshed in what multiplicity of political, social and gender relations, are engaging in rural development? And what rights and visions of development are invoked in their engagements? In responding to these questions, the following chapters reveal that despite their scripting as backward, 'vulnerable', and instrumentally 'empowered' mediators of national modernity, rural women are using the knowledges, expectations, organizational and institutional tools and resources produced by and for development, for purposes not always intended, and with sometimes unpredictable consequences for both local development outcomes and gender relations.

\section{CHAPTER OUTLINE}

Our organization of chapters reverses the perspective of much of the existing literature on women, gender and rural development in China, which either presents an analysis of the impacts of rural development on women and gender relations (see, for example, Han and Su 2006; World Bank 2006), or explores top-down strategies to transform gender relations by increasing women's participation in rural development (Chen, Lanyan 2008). Unwittingly, this literature reproduces the problematic assumptions that women in 'underdeveloped' communities are the passive recipients or victims of other people's visions of development, or, alternately, those who, with proper guidance, might become virtuous instruments of national development-as-equality. We aim to make a modest contribution to destabilizing the hierarchies of knowledge, power and agency inherent in that conceptual structuring by literally putting rural women first. Thus, Part I explores the agency of women in the context of land developments, intra-household distributions of labour and leisure, and public cultural performances; Part II examines interactions between state and NGO development policies relating to population policy, land rights and education, and social institutions; and Part III focuses on the roles played by NGOs, overseas-funded projects and global discourses in the 'empowerment' of women in rural China. 


\section{Part I: Women Shaping Development}

Urban-rural integration is one of the strategic goals of China's 'new' approach to rural development. In Chapter 1, Sargeson and Song draw on a comparative study of three sites to analyse women's agency in villages' determination of citizenship and distribution of benefits from urban land development. In their research sites, the authors report, men vastly outnumbered women in village rule-making bodies and, consequently, decided on villagers' citizenship and eligibility to share in compensation for land loss. And, in each site, the rules flouted constitutional guarantees of gender equality, prompting excluded women to challenge the rules.

How women claimed equal citizenship in these urbanizing communities, and with what degree of success, was shaped by local structures and institutions of political authority. In Changsha, Hunan Province, the centralized, top-down management of land development meant women were relatively successful in contesting gender discrimination in compensation distribution, and in securing commitments from government to provide social protections for expropriated villagers. This represented an example of what one might term a 'virtuous cycle', involving the actions of a developmental state, women's active participation in the deliberative life of the community, and citizens' realization of entitlements as members of an inclusive, 'modern' nation. In contrast, around the outskirts of the provincial capital of Fujian, Fuzhou, women were marginalized not only from village organizations and decision making, but also from local state agencies and remediation policies and practices. This closed off opportunities for 'Fuzhou women to exercise the types of autonomous, rightful agency demonstrated by women in Changsha' (Chapter 1, p. 44) prompting them instead to emphasize their membership of, and align their entitlement claims with, androcentric villages and households. Compared to the other sites, in Fuzhou not only did women lose most in terms of their livelihoods, entitlements and potential agency as national citizens, but their exclusion increased community inequalities and undermined 'social harmony' in the course of land development. The authors show, therefore, that the ways in which questions of gender and citizenship are dealt with at the local level are central to the efficacy of urban-rural integration as a developmentalist strategy.

In Chapter 2, Huang draws on fieldwork in Lianhe, a village in Hubei Province, to examine generational shifts in the gender distribution of leisure. Her findings offer a fascinating corrective to both the Marxist and liberal feminist development discourses propagated by the Chinese state and Women's Federation, and contribute to more recent feminist literature showing the complexity of interrelations between intra-household 
gender relations and relations of production. In Lianhe, economic development has reduced the labour intensity of agricultural and domestic work, and increased the time and money that villagers are able to spend on leisure. This leads Huang to ask: 'How has the rise of leisure affected the linkage between 'labour' and 'gender equality' in leisure within households? Huang reports that while elderly women in Lianhe had little conception of 'leisure', and did not begrudge the disproportionate time and money their husbands spent on leisure, younger generations of women demanded that their husbands share leisure resources more equally. The author explains older women's 'self-sacrifice' and younger women's 'selective self-sacrifice', as a consequence of women's changing participation in paid employment, and corresponding changes in responsibility for unpaid domestic work within households. The self-sacrifice narrative of the oldest generation of women was a self-serving discursive strategy aimed at highlighting their unpaid contribution to the family, thus enhancing their security. Younger generations of women, in contrast, argued that their monetary contributions towards the household entitled them to rest and 'play'. Moreover, they were aware that their husbands' relative power in the family would decline with age as their income contributions diminished. When women age and no longer are employed, however, their domestic work and childcare still provide them with a measure of influence in the family. Younger women, therefore, did not feel the same need to sacrifice their leisure for their husbands, but did devote time and money to their children.

Yet even in households in which women earned a relatively large cash income, greater gender equality in leisure distribution was by no means assured. In such cases, husbands sometimes felt their status as males was threatened, and sought to shore up their 'face' by demanding a greater share of leisure resources. Some women were reluctant to press their case for fear of domestic violence, and because women's 'assertiveness' was blamed by community members for causing family disharmony. Hence, Huang concludes, husband-wife arguments over the distribution of leisure resources among the younger generations are the result of complex links between changing labour patterns associated with economic development, perceptions of the relation between paid labour and leisure, and norms of fairness and gender-appropriate behaviours in the village.

Chapter 3 shifts our attention to the agency of ethnic minority women in state-sponsored 'cultural development'. Often involving significant changes to lifestyles, authority structures and gender relations in China's ethnic minority communities, such cultural development projects are generally motivated by a range of desires of both state and non-state actors, for the economic benefits of cultural tourism, the recognition 
and conservation of local cultures, and the participation by non-Han populations in a strong, 'modern' state. Ingram and five Kam co-authors, discuss what cultural development and 'taking the stage' in song performances mean to women in a Southern Kam community in Guizhou Province.

Although historically, women and men equally were recognized as 'song experts' in Kam villages, in the state's 'development' of Kam musical culture since 2000, women have been excluded from the design of cultural policy and management of staged performances. However, because many men and young women have left the community for work or study, song performances have increasingly relied on the participation of older Kam women. For all this, the authors do not depict the Kam singers as mere victims of state efforts to exoticize, essentialize and exploit them. Rather, they argue that Kam women actively support, collaborate in, and benefit from the staged song performances. Indeed, women derive considerable economic, cultural and social capital from participating in the performances, and this has led to changes in Kam women's positioning within their households and the community. In particular, the singers make money and gain opportunities to travel. Performances enhance their selfconfidence and provide new models of Kam femininity for young women, as well as changing the attitudes of their husbands and other men towards them. Hence, Ingram (as main author) concludes, 'state sponsorship [of the development of Kam song performances] . . has provided women with a legitimate foundation from which they can act to develop their own culture and cultural practices in ways that are appropriate for their own communities, and has been a legitimate source to draw upon to validate actions that challenge gendered cultural norms' (Chapter 3, p. 89).

\section{Part II: Tangled Ties: Policies, Institutions and Discourses}

In Chapter 6, Ross refers to Stromquist's characterization of gender issues as 'wicked problems', 'complex, interrelated, and less amenable to technical or scientific solutions since they depend primarily on value preferences' (Chapter 6, p. 144). In Part II, we take a look at some of the complex interrelations - the tangled ties - between development policies, global, national and local constructions of gender, and donor-funded projects, and rural social institutions, including virilocal marriage, ${ }^{5}$ patriarchal kinship and inheritance practices, and son preference.

The first two chapters focus on the gender dimensions of what has been a core element in the post-Mao Chinese state's strategy for development; control over reproduction. In the late 1970s, concerned that population growth was threatening economic development, Chinese state leaders 
introduced stringent limits on reproduction. These measures rolled into what became known as the 'one-child' policy, which greatly reduced population growth, but also produced contradictory social effects. On the one hand, many girls benefited from the state's emphasis on raising fewer 'quality' children, and their parents' greater investment in their health and education. On the other hand, the population measures indirectly exacerbated gender inequalities and discrimination against women (Greenhalgh and Winckler 2005: 245-284). In particular, many women were pressured by government to have late-term abortions and some of those who gave birth to girls were subjected to domestic violence or divorce. The infanticide of baby girls and sex-selective abortions produced a growing sex ratio at birth. To try to resolve these problems, Bossen argues in Chapter 4 that the state population policy itself became gendered, as local governments effectively converted the 'one-child' policy into a 1.5 child policy that permitted rural families with one daughter to try for a son, and provided 'compensatory' awards to couples with daughters. Despite these changes, distortions in the sex ratio continued to grow, and this, rather than aggregate population growth, began to be viewed as an impediment to 'people-led development' and the creation of an 'harmonious society'. At the same time, however, China's population planners argued that their policies were not the sole cause of the problem, because similarly skewed sex ratios were evident in India, and, until very recently, South Korea. Instead, China's sex ratio was attributed to rural people's 'needs' and traditional preference for sons.

Clearly, however, a tradition of 'son preference' does not explain the significant regional variations in sex ratios across China's countryside. Bossen accounts for these variations by examining intersections between three variables: the ways in which land and housing rights are allocated in villages; lineage solidarity; and villagers' tolerance for uxorilocal marriage. Drawing on a comparative study of Huang Tu, Henan Province, and Song Gou, Yunnan Province, she argues that variations in the strength of patriliny and virilocality exert a strong effect on household reproductive choices and consequent sex ratios. In Huang Tu, where there were dominant lineages, and neither uxorilocal marriages nor inheritance of property by daughters was tolerated, the incentive to have sons was particularly strong. Sex ratios correspondingly were highly skewed. In Song Gou, in contrast, there was no dominant lineage, uxorilocal marriages were tolerated, and sex ratios were normal. But until 2000, land had been readjusted to accommodate changes in household size in Huang $\mathrm{Tu}$, whereas Song Gou had not readjusted land since the 1980s. Bossen therefore suggests that the strength of patriliny and virilocality may have a greater impact on sex ratios than villages' land adjustment policies.

In Chapter 5, Eklund examines the issue of son preference from the 
perspective of the state's Care for Girls Campaign. This Campaign has sought to overcome son preference by means of awareness-raising and preferential policies for families with daughters. Eklund argues that the Campaign is underpinned by a state narrative that attributes the phenomenon of son preference primarily to the material needs, 'feudal' cultural traditions and discriminatory actions of villagers. Reflecting this, the awareness-raising components of the Campaign promote reproductive behaviour free from son preference as 'modern', 'scientific' and 'civilized'. Campaign posters and slogans seek to portray a positive, 'modern' role for daughters, while financial incentives enable parents to invest in the 'quality' of daughters. Eklund argues, however, that the Campaign's aim is undermined, both by contradictions among the Campaign's messages, and disparities between Campaign messages and villagers' needs and gender norms. As an example of the former problem, family planning posters highlight stereotypically 'female' traits of daughters, such as being pretty and caring, implicitly suggesting that other, perhaps more important things, such as economic security, are best provided by sons. Drawing on fieldwork in Anhui Province, Eklund refutes the proposition that the importance of male agricultural labour contributes to son preference in villages. Male manual labour has become far less significant in agriculture over the last few years, due to industrialization and mechanization, and the large-scale outmigration of men. Consequently, narratives focusing on rural households' need for male agricultural labour as the reason for son preferences simply serve to entrench public perceptions of rural 'backwardness'. Also missing from the state narrative is an acknowledgement of the role of population policies in valorizing sons over daughters. For example, when population policies were amended in the late 1980s to allow rural families with only one daughter to have a second child, this effectively reinforced the understanding that sons are more valuable than daughters. Similarly, the provision of compensatory benefits to families with daughters, but not to those with sons, contradicts the message of equal value.

How is gender socialization shaped by developments in rural education? In Chapter 6, Ross examines an 'affirmative action' project that sought to improve the years and quality of schooling received by rural girls. Ross shows that the developmentalist discourse propagated top-down by state education policy, and bottom-up external education programmes supported by NGOs and donor agencies, is closely tied to China's integration into global markets. Educated girls in this essentialist, instrumental discourse, become the 'mothers of development', the means of reducing rural poverty, improving the population's health and quality, and achieving national 'modernity'. Hence, the schools in which the Spring Bud 
programme was implemented functioned as civilizing places that both emphasized rural 'underdevelopment', and fed parents' and daughters' desire for, and anxiety about entry into higher education as an escape from rurality. Yet in these civilizing places, biological essentialism and gender stereotypes continued to construct a 'gender trap within the market solution' of girls' schooling. Ross concludes that although state education policies and programmes like Spring Bud have indeed contributed to major improvements in girls' educational enrolment and attainment, the developmentalist assumptions informing educational interventions undermine the value of education to girls and women. Told that they have equal rights with men in all spheres of life, girls nevertheless learn that they are inferior to boys with regard to some of the most sought-after skills and occupations. Meanwhile, their status as 'backward peasants' is reinforced, both through increasingly available technologies of communication, such as television and the internet, and through state policies that privilege the urban.

\section{Part III: The Global, the Local and the Project}

A corollary of China's integration with global regimes has been the increasing circulation within China of global development discourses, institutions and funding, as well as a proliferation of non-state development agencies. In Part III, we ask: through what avenues and processes have global development concepts and strategies, and the greater participation of non-state actors and new technologies, shaped understandings and practices relating to gender and development in rural China? What are the consequences of this for development actors, rural women, and gender relations in China's countryside?

Zhao Jie, a leading women's activist and head of the Gender and Participation Research Centre of the Yunnan Academy of Social Sciences (GPRC), critically interrogates how global GAD discourses and projects have affected her own participation in development projects in rural Yunnan in Chapter 7. Zhao suggests that development interventions in general, and GAD projects in particular, are underpinned by a self-serving, neo-colonial discourse that continually reproduces power inequalities, and freeze-frames rural women in Yunnan as stereotypical subjects of development that are both culturally diverse and uniformly 'backward'. Meanwhile, Yunnan women's own expressions of their interests are marginalized, and the social, structural inequalities which shape patterns of disadvantage and need remain unchallenged.

In order to effectively promote gender equity and social justice, Zhao writes, development practitioners in China need to interrogate their 
presumptions, interests and positions, and make better use of existing structures to improve the possibilities for rural women to represent their own needs in development. In the second half of her chapter, she reports on two projects through which she and fellow members of the GPRC have tried to do this. The first focuses on the potential for village governments to represent and realize local women's interests, but recognizes that, to date, members of village governments have generally lacked the gender awareness, skills and resources to achieve that potential. The project therefore makes use of existing Party and government grassroots training resources to increase awareness among Party School leaders and teachers about gender concerns, and state policies and laws regarding gender equality, and to instruct village leaders on methods of gender analysis and the incorporation of gender equality into local policy. The second project involves training female leaders of minority ethnic associations in gender analysis, participatory governance, gender-sensitive development planning and other areas, so that they can lead the way in promoting genderequitable, sustainable development in their communities in the future.

Wesoky offers a different perspective on rural women's interaction with global feminist and development discourses in Chapter 8. As she notes in the first part of her chapter, 'empowerment' has become a key goal of the projects that Chinese women's NGOs run with funding and guidance from overseas development agencies. How does rural women's 'empowerment' work when the discourses and resources of globalized feminism encounter authoritarian, gendered local-level power structures? In responding to this question, Wesoky's chapter draws on the stories of two rural Chinese women in Hebei whose lives have been shaped through their engagement with the leading overseas-funded NGO, Nongjianü. The first woman, $\mathrm{Li}$, was trained by Nongjianü, and then stood for election and became head of the local Village Committee. The second woman, $\mathrm{Xu}$, worked as the principal of a training school in Beijing founded by Nongjianü, then returned to her village to set up an NGO committed to suicide prevention and rural women's health support. In challenging local-level power dynamics, both women met with strong local resistance. Nevertheless, they claimed to have been empowered through their engagement with Nongjianü and their subsequent work, and to have improved the lives of other village women.

Wesoky identifies three main avenues through which globalization has affected the activities of local activists like $\mathrm{Li}$ and $\mathrm{Xu}$, and local gender power dynamics. The first is local-global communications and media, which now connect even poor, otherwise isolated Chinese villages into extensive social and political networks. As Wesoky shows, this can have both positive and negative ramifications for women who challenge local power relations. Media coverage unfavourable to local officials invites 
repression. At the same time, however, the exposure of repression might gain sympathy from a broader audience and legitimate women's activities. Second, globalization has broadened the agenda of NGOs, and put pressure on existing state organizations and the Women's Federation to democratize and address new concerns. Finally, globalization has presented new challenges to local discourses about gender and power. Through their exposure to global concepts and norms about gender equality and women's 'empowerment', activists like Li, for example, gain the skills and confidence to contest local assumptions that women are unfit to exercise political power in the village.

In the concluding chapter, Yang presents a less positive account of global-local interactions intended to 'empower' rural Chinese women. Yang's case study examines a donor-aided project in north-western Inner Mongolia, which included as project goals gender equity in land rights, community participation and the 'empowerment' of local women. Through three vivid, ethnographic snapshots of project activities, Yang shows how the gender participatory outcomes of the Grassland Management Project (GMP) were shaped by a complex mix of political and operational constraints, and local cultural and institutional limitations to participatory thinking and practice. In some cases, measures to increase women's participation and ensure gender equity introduced during the project directly conflicted with existing practices relating, for example, to the distribution of land-use rights. In others, they were stymied by the discriminatory attitudes of male power holders. And throughout the project, participation and equity were repeatedly undermined by the bureaucratic work practices of project officials and their failure to devote sufficient resources to changing gender norms.

Nonetheless, Yang notes that, through the GMP, women in the project sites gained a new awareness of their rights to land. Furthermore, like Sargeson and Song, Ingram and co-authors, and Wesoky, Yang rejects the representation prevalent in the literature on China's rural development, that rural women are merely passive recipients, victims or instruments of the state's or global visions of development. Certainly, the project failed to increase 'participation' in the specific ways that the project designers originally envisaged; however, Yang's study also points to high levels of agency among local women, sometimes expressed in their 'incorrect' deployment of project resources, as, for example their expenditure of microcredit on family medical expenses rather than pig raising. And in yet other cases, women's agency was expressed precisely in a refusal to respond to hectoring from project workers, or by women literally walking away from 'participatory development' activities.

In sum, the nine chapters that comprise this volume present valuable 
case studies of gender relations and women's varying involvement in development across China, from Inner Mongolia in the north, to Guizhou in the south. Taken together, they provide important empirical evidence of the contingent construction of the subject 'rural woman', and the centrality of gendered power relations in shaping both 'development' and the agency exercised by differently positioned women in rural development.

\section{NOTES}

1. The Women's Federation is a 'mass organization'. As such, it is officially separate from the state (that is, the Communist Party and the government). However, the state funds the Women's Federation, appoints its leadership and determines its policies. For this reason, the Women's Federation is sometimes referred to as a 'government-organized NGO' or GONGO (see Ross, this volume).

2. The hukou, or household registration, system was introduced in the late 1950s. Chinese citizens are registered at birth as holding either rural, agricultural or urban, nonagricultural hukou. It is very difficult to transfer from a rural to an urban hukou. Thus, the majority of rural migrants residing in cities have only temporary resident status rather than local, urban hukou. As such, and despite the state's efforts to reform the situation, they face discrimination, exploitation and a number of restrictions on their rights as citizens. For further detail, see Wang, Fei-Ling (2005).

3. For an introduction to, and critique of, Women in Development (WID) and Gender and Development (GAD) discourse, see Razavi and Miller (1995). See also, Yang, this volume and Zhao, this volume.

4. See note 3 above.

5. The majority of marriages in rural China are 'virilocal', by which is meant that the woman moves to her husband's home at marriage. In some rural areas, however, uxorilocal marriages, in which the man moves to his wife's home, have become more common in recent years. For further discussion, see Bossen, this volume. 